\title{
Exploring the influence of culture conditions on kefir's anticancer properties
}

\author{
Ma'mon M. Hatmal, ${ }^{*}$ Abeer Nuirat, ${ }^{*}$ Malek A. Zihlif, $†$ and Mutasem O. Taha ${ }^{1}$ \\ *Department of Medical Laboratory Sciences, Faculty of Allied Health Sciences, The Hashemite University, Zarqa 13133, Jordan \\ †Department of Biochemistry, Faculty of Medicine, The University of Jordan, Amman 11942, Jordan \\ ‡Drug Discovery Unit, Department of Pharmaceutical Sciences, Faculty of Pharmacy, The University of Jordan, Amman 11942, Jordan
}

\begin{abstract}
Cancer is a major health problem in many parts of the world. Conventional anticancer treatments are painful, expensive, and unsafe. Therefore, demand is increasing for cancer treatments preferentially in the form of functional foods or nutritional supplements. Kefir, a traditional fermented milk dairy product, has significant antimutagenic and antitumor properties. This research addresses the hypothesis that kefir's anticancer properties are affected by fermentation conditions. Initially, kefir extracts prepared under standard conditions were screened against 7 cancer cell lines using the tetrazolium dye 3-(4,5-dimethylthiazol2-yl)-2,5-diphenyltetrazolium bromide colorimetric assay. Colon cancer and chronic myelogenous leukemia cells were found to be most susceptible to kefir extracts. Subsequently, a factorial design was implemented to assess the effects of 3 fermentation times $(24,48$, and 72 h), 3 kefir-to-milk ratios (2, 5, and $10 \% \mathrm{wt} / \mathrm{vol})$, and 3 fermentation temperatures $\left(4,25\right.$, and $\left.40^{\circ} \mathrm{C}\right)$ on kefir's anticancer properties. Remarkably, exploration of the fermentation conditions allowed the anticancer properties of kefir to be enhanced by 5 - to 8 -fold against susceptible cell lines. Overall, these results demonstrate the possibility of optimizing the anticancer properties of kefir as a functional food in cancer therapy.
\end{abstract}

Key words: kefir, fermentation conditions, factorial design, cancer cell lines

\section{INTRODUCTION}

Cancer is a significant health problem in many parts of the world. The number of cancer patients is expected to reach 11.5 million in 2030 worldwide (Farmer et al., 2010). Current conventional cancer treatments (e.g., chemotherapy and radiation) are painful, expensive, and unsafe (Fulda, 2004; Fulda and Debatin, 2006;

Received July 20, 2017.

Accepted January 17, 2018.

${ }^{1}$ Corresponding author: mutasem@ju.edu.jo
Ghoneum, 2014). Hence, there is great current interest in the development of new cancer therapies.

Kefir grains are composed of a complex symbiotic mixture of bacteria and yeast (Fulda, 2004; Fulda and Debatin, 2006; Gao et al., 2013). Kefir is a dairy product produced by fermentation of milk using kefir grains (Liu et al., 2002; de Moreno de LeBlanc et al., 2007; Ghoneum, 2014). Kefir exhibits significant health benefits including pronounced anticancer properties (Liu et al., 2002; Chen et al., 2006; de Moreno de LeBlanc et al., 2007). The main products of kefir fermentation are lactic acid, ethanol, $\mathrm{CO}_{2}$, and many aromatic compounds (Farnworth, 2005; Guzel-Seydim et al., 2011; Altay et al., 2013). As in yogurt, the lactose content is reduced in kefir; however, kefir is rich in free AA and peptides (Wang et al., 2008; Ahmed et al., 2013). The beneficial health characteristics of kefir are attributed to protein, vitamins, antioxidants, minerals, and certain biogenic compounds present in the grains (Farnworth, 2003; Ahmed et al., 2013; de Oliveira Leite et al., 2013). Traditionally, kefir beverage is prepared by adding kefir grains $(2-10 \% \mathrm{wt} / \mathrm{vol})$ to pasteurized milk. After a period of fermentation lasting over approximately 24 h (Hallé et al., 1994) and under mesophilic conditions (Motaghi et al., 1997), the grains are removed by filtration. The resulting filtrate is ready for consumption. The grains can be reused in subsequent fermentation (Hallé et al., 1994).

Many studies have established the antitumor properties of kefir against breast cancer (de Moreno de LeBlanc et al., 2006; Chen et al., 2007; de Moreno de LeBlanc et al., 2007), colorectal cancer (Farnworth and Mainville, 2003; Khoury et al., 2014), malignant T lymphocytes (Maalouf et al., 2011), and lung carcinoma (Furukawa et al., 2000). The cell-free fraction of kefir was found to inhibit cancer cell proliferation by cell cycle arrest and induction of apoptosis through upregulating bax and downregulating bcl-2 (Gao et al., 2013). Apparently, the main kefir polysaccharide, kefiran, is responsible for the antitumor properties of kefir (Sharifi et al., 2017). Additionally, kefir contains unique sphingomyelins that promote the secretion of antiproliferative cytokines (particularly IFN- $\beta$ ) in human osteosarcoma cells (Osada et al., 1993; Sharifi et al., 2017). 
Table 1. The concentration of the extract that inhibits cell growth by $50 \%\left(\mathrm{IC}_{50}\right)$ values $(\mathrm{mg} / \mathrm{mL})$ of kefir extracts prepared under standard conditions $\left(24 \mathrm{~h}, 5 \% \mathrm{wt} / \mathrm{vol}\right.$, and at $\left.25^{\circ} \mathrm{C}\right)$ and doxorubicin hydrochloride (positive control) against different cancer cell lines

\begin{tabular}{lccccc}
\hline & \multicolumn{2}{c}{ Kefir extract } & & \multicolumn{2}{c}{ Doxorubicin } \\
\cline { 2 - 3 } \cline { 5 - 6 } Cancer cells $^{1}$ & $\begin{array}{c}\mathrm{IC}_{50} \\
(\mathrm{mg} / \mathrm{mL})\end{array}$ & $\mathrm{SD}$ & & $\begin{array}{c}\mathrm{IC}_{50} \\
(\mathrm{mg} / \mathrm{mL})\end{array}$ & $\mathrm{SD}$ \\
\hline K562 & 11.36 & 1.338 & & $2.84 \times 10^{-4}$ & 0.019 \\
HCT116 & 17.39 & 2.157 & & $0.21 \times 10^{-4}$ & 0.002 \\
SKOV3 & 26.5 & 5.429 & & $2.78 \times 10^{-4}$ & 0.085 \\
MCF-7 & 43.07 & 4.343 & & $0.42 \times 10^{-4}$ & 0.010 \\
PANC1 & 42.39 & 3.740 & & $2.43 \times 10^{-4}$ & 0.039 \\
A549 & 35.27 & 0.919 & & $0.61 \times 10^{-4}$ & 0.006 \\
PC3 & 32.74 & 3.426 & & $4.17 \times 10^{-4}$ & 0.144 \\
Fibroblasts (control) & 72.38 & 4.156 & & $29.69 \times 10^{-3}$ & 12.380 \\
\hline
\end{tabular}

${ }^{1}$ K562 = chronic myelogenous leukemia; HCT116 = colon cancer; SKOV3 = ovarian cancer; $\mathrm{MCF}-7=$ breast cancer; $\mathrm{PANC} 1=$ pancreas cancer; A549 = lung carcinoma; PC3 = prostate cancer.

Interestingly, despite extensive studies on the antitumor properties of kefir, the literature lacks any attempt to explore the effects of fermentation conditions on kefir's anticancer properties. Accordingly, the current research addresses the hypothesis that kefir's anticancer properties are significantly influenced by fermentation conditions.

The current study commenced by scanning the anticancer activities of kefir extracts against breast cancer (MCF-7), chronic myelogenous leukemia (K562), lung carcinoma (A549), pancreas cancer (PANC1), prostate cancer (PC3), ovarian cancer (SKOV3), and colorectal cancer (HCT116) cell lines, as in Table 1.

Subsequently, we implemented factorial design using 3 factors, namely, fermentation times $(24,48$, and 72 $\mathrm{h}$ ), fermentation temperatures $\left(4,25\right.$, and $\left.40^{\circ} \mathrm{C}\right)$, and kefir-to-milk ratios $(2,5$, and $10 \% \mathrm{wt} / \mathrm{vol})$, to explore the effects of fermentation conditions on the anticancer properties of kefir against sensitive cancer cells. The investigated fermentation conditions were selected in such a way to mimic routine conditions used by communities in different geographical areas. For example, in its Tibet home region, kefir is normally brewed at low temperatures over few days, whereas in hot geographical zones it is usually fermented more rapidly.

\section{MATERIALS AND METHODS}

\section{Materials}

The following materials were used in the project and were purchased from the corresponding companies. Fetal bovine serum (HyClone, Logan, UT), HEPES buffer (HyClone), McCoy's 5a Medium Modified (HyClone), Dulbecco's modified Eagle medium (DMEM) high glucose medium with L-glutamine (Capricorn, Ebsdorfergrund, Germany), DMEM Hams F12 medium with L-glutamine (Capricorn), RPMI 1640 medium with L-glutamine (Capricorn), Matrix 96-Well Tissue Culture Treated Plates (Sigma-Aldrich, St. Louis, MO), L-glutamine (Capricorn), sterile syringe filter pore $0.22 \mu \mathrm{m}$ (Millipore, Billerica, MA), doxorubicin $\mathrm{HCl}$ (Sigma-Aldrich), PBS (Capricorn), the tetrazolium dye 3-(4,5-dimethylthiazol-2-yl)-2,5-diphenyltetrazolium bromide (MTT) kit (Promega, Madison, WI), and dimethyl sulfoxide (Gibco, Waltham, MA).

The tested cell lines and their ATCC numbers (in parentheses) are as follows: HCT116 (CCL247), MCF7 (HTB22), K562 (CCL243), A549 (CCL185), PANC1 (CRL1469), PC3 (CRL1435), and SKOV3 (HTB77).

\section{Kefir Production and Preparation of Kefir Extracts}

Kefir grains were cultured in pasteurized full-fat cow milk $(200 \mathrm{~mL}$, with $3.1 \mathrm{~g}$ of fat, $3.1 \mathrm{~g}$ of protein, $4.7 \mathrm{~g}$ of carbohydrate, $100 \mathrm{mg}$ of calcium, and $80 \mathrm{IU}$ of vitamin $\mathrm{D}_{3}$, Al-Marai Dairy Company, Jordan) in screw-capped glass containers without stirring, and at different kefir grain-to-milk ratios $(2,5$, and $10 \% \mathrm{wt} / \mathrm{vol})$, fermentation times $(24,48$, and $72 \mathrm{~h})$, and fermentation temperatures $\left(4,25\right.$, and $\left.40^{\circ} \mathrm{C}\right)$, as in Table 2 .

Following culture, kefir grains were removed by filtration using plastic colander, then the extracts were centrifuged at $3,000 \times g$ for $20 \mathrm{~min}$ at $4^{\circ} \mathrm{C}$. The supernatant fractions were lyophilized overnight at $-50^{\circ} \mathrm{C}$ (Freeze Dry System, Telstar, Spain) then stored at $-80^{\circ} \mathrm{C}$. Before testing against cell lines, the lyophilized supernatant samples were serially diluted in corresponding culture medium (see Antiproliferation Assay below), adjusted to $\mathrm{pH} 7.0$ using $\mathrm{NH}_{4} \mathrm{OH}$ (10 M, SigmaAldrich), and passed through a $0.22-\mu \mathrm{m}$ Millipore filter.

\section{Antiproliferation Assay}

In the initial screening step (Table 1), cancer cells were seeded into 96-well plates at the following cellular densities (in parentheses): K562 $\left(3.5 \times 10^{4}\right.$ diluted in RPMI 1640 medium $)$, HCT116 $\left(5 \times 10^{3}\right.$ diluted in DMEM high glucose medium $)$, SKOV-3 $\left(7 \times 10^{3}\right.$ diluted in McCoy's 5a medium), MCF-7 $\left(8 \times 10^{3}\right.$ diluted in RPMI 1640 medium), PANC1 $\left(8 \times 10^{3}\right.$ diluted in DMEM high glucose medium), A549 $\left(5 \times 10^{3}\right.$ diluted in DMEM high glucose medium), PC3 $\left(5 \times 10^{3}\right.$ diluted in DMEM high glucose medium), and fibroblasts (control, $5 \times 10^{3}$ diluted in DMEM high glucose medium). Subsequently, cells were incubated for $24 \mathrm{~h}$ at $37^{\circ} \mathrm{C}$ in $5 \%$ $\mathrm{CO}_{2}$ humidified atmosphere using a NuAire incubator (Plymouth, MN). Thereafter, cells were treated with 
different concentrations of lyophilized kefir $(0.39,0.78$, $1.56,3.125,12.5,25,50$, and $100 \mathrm{mg} / \mathrm{mL}$ ) prepared under standard conditions (i.e., kefir-to-milk ratio $5 \%$ wt/vol, fermentation time $24 \mathrm{~h}$, and fermentation temperature $25^{\circ} \mathrm{C}$ ). Medium alone was used as a negative control. Subsequently, treated cells were incubated for $72 \mathrm{~h}$ at $37^{\circ} \mathrm{C}$ in $5 \% \mathrm{CO}_{2}$ humidified atmosphere using a NuAire incubator. The experiments were repeated in duplicates.

In the subsequent exploration of kefir fermentation conditions (Table 2), susceptible HCT116 and K562 cancer cells (see Results section) were seeded into 96well plates at cellular densities of $5 \times 10^{3}$ and $3.5 \times$ $10^{4}$, respectively. After incubation over $24 \mathrm{~h}$ at $37^{\circ} \mathrm{C}$ in $5 \% \mathrm{CO}_{2}$ humidified atmosphere using a NuAire incubator, cells were treated with different concentrations of lyophilized kefir extracts $(0.79,1.56,3.125,6.25,12.5$, $25,50,100$, and $180 \mathrm{mg} / \mathrm{mL}$ ) prepared under fermentation conditions as in Table 2. Medium alone was used as negative control. Subsequently, treated cells were incubated for $72 \mathrm{~h}$ at $37^{\circ} \mathrm{C}$ in $5 \% \mathrm{CO}_{2}$ humidified atmosphere using NuAire incubator. The experiments were repeated in duplicates.
At the end of the incubation time, cells were washed with PBS, fresh medium $(100 \mu \mathrm{L})$, and MTT solution (provided in the CellTiter 96 Cell Proliferation Assay kit, $10 \mu \mathrm{L}$ ) was added to cells and they were incubated further for $4 \mathrm{~h}$ at $37^{\circ} \mathrm{C}$ in $5 \% \mathrm{CO}_{2}$ humidified atmosphere using the NuAire incubator. Finally, dimethyl sulfoxide $(100 \mu \mathrm{L})$ was added to the reaction mixture and incubated overnight under dark conditions to ensure complete dissolution of the formazan crystals.

The concentration of the extract that inhibits cell growth by $50 \%\left(\mathbf{I C}_{50}\right)$ values were determined from kefir extract concentration versus percent inhibition curve calculated by Prism software (GraphPad Software, La Jolla, CA).

\section{Statistical Analysis}

All statistical tests were performed using GraphPad Prism 5.0 for Windows (GraphPad Software). The statistical differences among $\mathrm{IC}_{50}$ of kefir extracts against HCT116 and K562 cell lines in Table 2 were determined by 1-way ANOVA multiple comparison test at a statistical significance of $P<0.05$.

Table 2. Different combinations of fermentation factors used in preparing kefir extracts and the corresponding anticancer concentration of the extract that inhibits cell growth by $50 \%\left(\mathrm{IC}_{50}\right)$ values

\begin{tabular}{|c|c|c|c|c|c|}
\hline \multirow{2}{*}{$\begin{array}{l}\text { Extract } \\
\text { number }\end{array}$} & \multicolumn{3}{|c|}{ Fermentation variable } & \multicolumn{2}{|c|}{$\mathrm{IC}_{50}$ value $^{1}( \pm \mathrm{SD} ; \mathrm{mg} / \mathrm{mL})$} \\
\hline & Time $(\mathrm{h})$ & Temperature $\left({ }^{\circ} \mathrm{C}\right)$ & $\%(\mathrm{wt} / \mathrm{vol})$ & HCT116 & K562 \\
\hline 1 & 24 & 4 & 2 & $6.99 \pm 0.52$ & $\mathrm{ND}^{2}$ \\
\hline 2 & & & 5 & $7.36 \pm 1.50$ & $3.68 \pm 1.47$ \\
\hline 3 & & & 10 & $2.11 \pm 0.26$ & $31.06 \pm 19.17$ \\
\hline 4 & & 25 & 2 & $6.72 \pm 1.44$ & $6.48 \pm 0.40$ \\
\hline 5 & & & 5 & $17.39 \pm 2.16$ & $11.36 \pm 1.34$ \\
\hline 6 & & & 10 & $4.97 \pm 1.80$ & $15.47 \pm 0.66$ \\
\hline 7 & & 40 & 2 & $10.0 \pm 2.80$ & $18.17 \pm 4.65$ \\
\hline 8 & & & 5 & $9.27 \pm 1.50$ & $9.98 \pm 3.03$ \\
\hline 9 & & & 10 & $2.6 \pm 0.12 \S$ & $3.7 \pm 0.83 \S$ \\
\hline 10 & 48 & 4 & 2 & $6.64 \pm 0.31$ & $44.85 \pm 0.12$ \\
\hline 11 & & & 5 & $9.27 \pm 0.33$ & $2.35 \pm 0.49 \S$ \\
\hline 12 & & & 10 & $2.39 \pm 0.04 \S$ & $2.11 \pm 0.05 \S$ \\
\hline 13 & & 25 & 2 & $5.58 \pm 0.22$ & $9.2 \pm 2.48$ \\
\hline 14 & & & 5 & $6.34 \pm 0.57$ & $5.31 \pm 1.86$ \\
\hline 15 & & & 10 & $14.02 \pm 1.58$ & $5.45 \pm 1.59$ \\
\hline 16 & & 40 & 2 & $5.82 \pm 0.18$ & $2.62 \pm 0.26$ \\
\hline 17 & & & 5 & $7.15 \pm 1.51$ & $12.21 \pm 1.34$ \\
\hline 18 & & & 10 & $8.67 \pm 0.55$ & $6.82 \pm 3.70$ \\
\hline 19 & 72 & 4 & 2 & $19.49 \pm 2.44$ & $10.76 \pm 0.54$ \\
\hline 20 & & & 5 & $15.24 \pm 0.49$ & $14.7 \pm 0.52$ \\
\hline 21 & & & 10 & $10.15 \pm 1.58$ & $20.58 \pm 3.71$ \\
\hline 22 & & 25 & 2 & $7.73 \pm 1.75$ & $6.19 \pm 0.18$ \\
\hline 23 & & & 5 & $12.17 \pm 1.41$ & $6.61 \pm 0.51$ \\
\hline 24 & & & 10 & $13.45 \pm 2.03$ & $10.22 \pm 1.17$ \\
\hline 25 & & 40 & 2 & $7.86 \pm 0.61$ & $32.67 \pm 8.98$ \\
\hline 26 & & & 5 & $5.38 \pm 0.54$ & $3.93 \pm 1.37$ \\
\hline 27 & & & 10 & $16.33 \pm 0.18$ & $28.58 \pm 0.40$ \\
\hline
\end{tabular}

${ }^{1}$ The experiments were repeated in duplicates. Cancer cell lines: HCT116 = colon cancer; K562 = chronic myelogenous leukemia.

${ }^{2} \mathrm{ND}=$ not determined because of significant measurement error.

$\S$ Indicates statistically significant superior anticancer $\mathrm{IC}_{50}$ values $(P<0.05$ using Student's $t$-test $)$. 

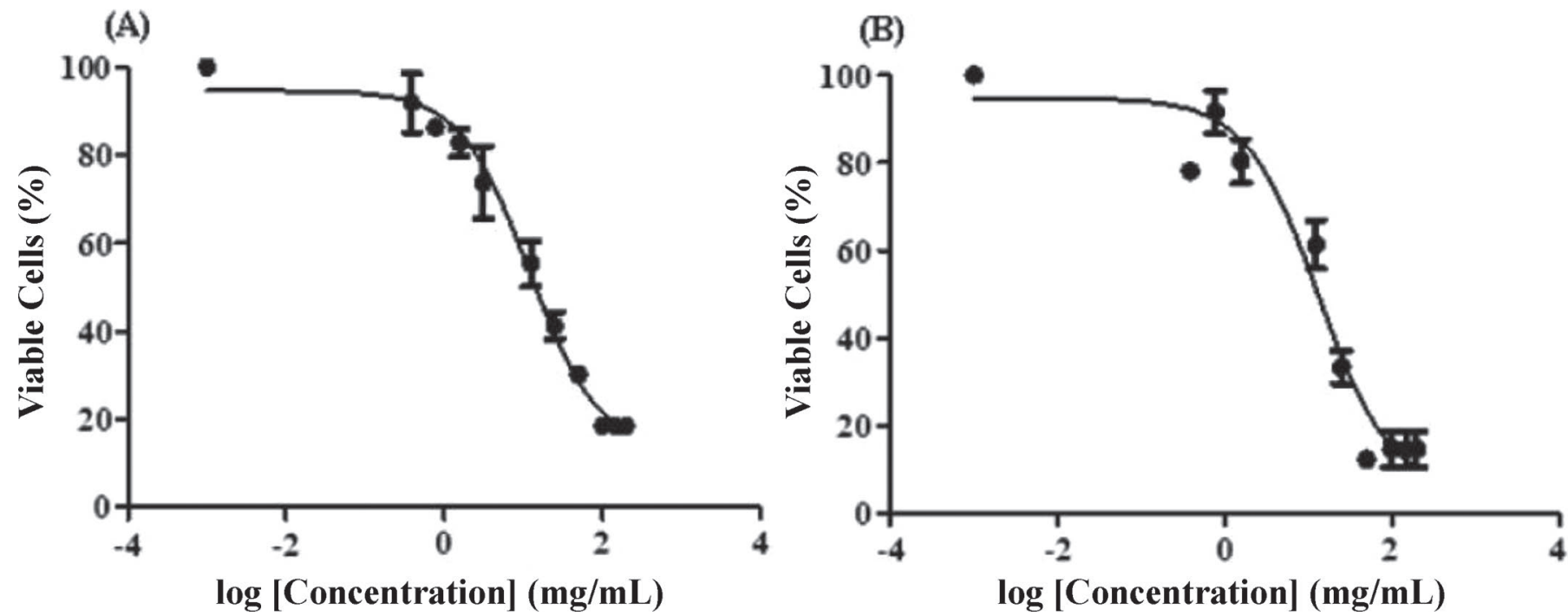

Figure 1. Antiproliferative effects of conventionally prepared kefir extract (prepared over $24 \mathrm{~h}$, and under $25^{\circ} \mathrm{C}$, using $5 \%$ wt/vol kefir-to-milk ratio) against chronic myelogenous leukemia (K562) and colon cancer (HCT116) cancer cell lines over a 72-h exposure time as determined using the tetrazolium dye 3-(4,5-dimethylthiazol-2-yl)-2,5-diphenyltetrazolium bromide assay. (A) Dose inhibition against the K562 cell line, and (B) dose inhibition curve against HCT116. The experiments were repeated in triplicates, and error bars represent SD of measurements.

\section{RESULTS}

\section{Scanning the Antiproliferative Effects of Kefir Against Cancer Cell Lines}

The cytotoxic effects of standard kefir extracts (prepared under standard fermentation conditions: over 24 $\mathrm{h}$ at $25^{\circ} \mathrm{C}$, and using a kefir-to-milk ratio of $5 \% \mathrm{wt} / \mathrm{vol}$ ) were explored against a panel of 7 human cancer cell lines over $72 \mathrm{~h}$ of exposure time. Table 1 compares the $\mathrm{IC}_{50}$ values of kefir with those of doxorubicin against tested cells.

As in Table 1, kefir extracts were found to be most effective against human K562 and HCT116 cells with $\mathrm{IC}_{50}$ values of 11.36 and $17.39 \mathrm{mg} / \mathrm{mL}$, respectively. This is the first time to report potent kefir cytotoxicity against K562 cells.

Figure 1 shows the corresponding dose-response curves of kefir against K562 and HCT116 cell lines. Clearly, cellular viability of both cancer cell lines decreased dramatically from $100 \%$ corresponding to kefir extract concentration of $1 \mathrm{mg} / \mathrm{mL}$ to level out at approximately $20 \%$ corresponding to kefir extract concentration of $100 \mathrm{mg} / \mathrm{mL}$. However, other cell lines and normal dermal fibroblasts (used as control) were much more resistant with $\mathrm{IC}_{50}$ values exceeding 20 $\mathrm{mg} / \mathrm{mL}$. In comparison, unsurprisingly, doxorubicin hydrochloride (used as positive control) showed much more potent antiproliferative effects against all tested cell lines including normal fibroblasts (which points to the excellent safety profile of kefir compared with doxorubicin).

\section{Effects of Kefir Fermentation Variables Against K562 and HCT116 Cells}

A series of kefir extracts were prepared employing different combinations of fermentation times $(24,48$, and $72 \mathrm{~h}$ ), fermentation temperatures $\left(4,25\right.$, and $\left.40^{\circ} \mathrm{C}\right)$, and kefir-to-milk ratios $(2,5$, and $10 \% \mathrm{wt} / \mathrm{vol})$. The resulting kefir extracts were tested against K562 and HCT116 cells. Table 2 summarizes the effects of kefir fermentation variables on corresponding cytotoxicities.

The extensive statistical assessment of studied fermentation conditions in Table 2 showed that fermentation time is the only factor that caused a statistically significant $(P<0.05)$ difference in the anticancer profiles of kefir extracts, such that longer fermentation times (i.e., $72 \mathrm{~h}$ ) reduced kefir's anticancer profiles against both cancer lines (regardless of fermentation temperatures or kefir-to-milk ratios).

Moreover, from Table 2, extract number 12 (prepared using kefir-to-milk ratio of $10 \% \mathrm{wt} / \mathrm{vol}$ over $48 \mathrm{~h}$ and under $4^{\circ} \mathrm{C}$ ) displayed the most pronounced combined cytotoxic effects against $\mathrm{K} 562$ and $\mathrm{HCT} 116\left(\mathrm{IC}_{50}=\right.$ 2.11 and $2.39 \mathrm{mg} / \mathrm{mL}$, respectively), which represent more than 5-fold statistically significant enhancement compared with kefir prepared under standard conditions (extract number 5 in Table $1, P<0.05$ using Student's t-test). Still, other fermentation conditions achieved statistically significant superior anticancer $\mathrm{IC}_{50}$ values $(P<0.05$ using Student's $t$-test, Table 2$)$ compared with standard kefir fermentation conditions. Figures 2 and 3 show ANOVA (1-way) presentations of 
significantly different kefir extracts against K562 and HCT116 cells $(P<0.05)$, respectively. Clearly, from the 2 figures, it is possible to categorize kefir extracts into 3 levels (i.e., potent, intermediate, and poorly potent) based on their corresponding anticancer profiles. However, it is rather hard to correlate any single fermenta- tion factor with anticancer activity except fermentation time as mentioned earlier. Interestingly, some fermentation conditions yielded significant cytotoxic properties against 1 of the 2 cell lines only (e.g., extracts 1 and 10 in Table 2, which show cytotoxic activity against HCT116 only).

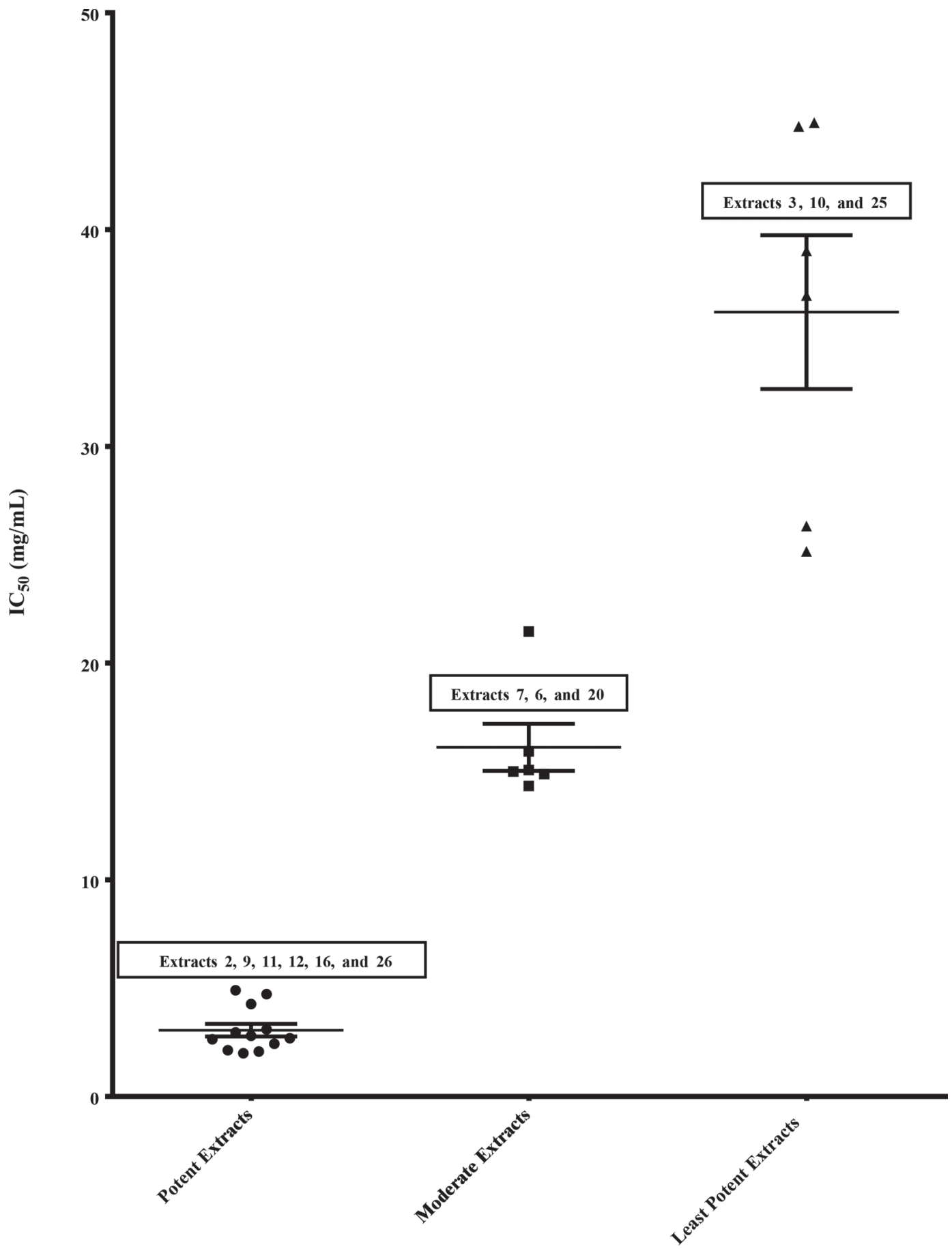

Figure 2. One-way ANOVA presentation of kefir extracts $(\mathrm{n}=24)$ that exhibit significantly different concentrations of the extract that inhibits cell growth by $50 \%\left(\mathrm{IC}_{50}\right)$ values against chronic myelogenous leukemia $(\mathrm{K} 562)$ cells $(P<0.05)$. Extract numbers are as in Table 2 . The error bars represent the $\mathrm{SD}$ of the $\mathrm{IC}_{50}$ measurements, and the middle bars represent the corresponding averages. 


\section{DISCUSSION}

Extensive statistical evaluation of data in Table 2 by comparing kefir's anticancer $\mathrm{IC}_{50}$ values obtained under different fermentation conditions, showed that the only factor to significantly influence kefir's anticancer prop- erties is fermentation time (regardless to fermentation temperatures or kefir-to-milk ratios). Shorter fermentation times (24 to $48 \mathrm{~h}$ ) yielded statistically significant $(P<0.05)$ superior anticancer profiles compared with longer fermentation time $(72 \mathrm{~h})$. These results are consistent with initial production of cytotoxic bioac-

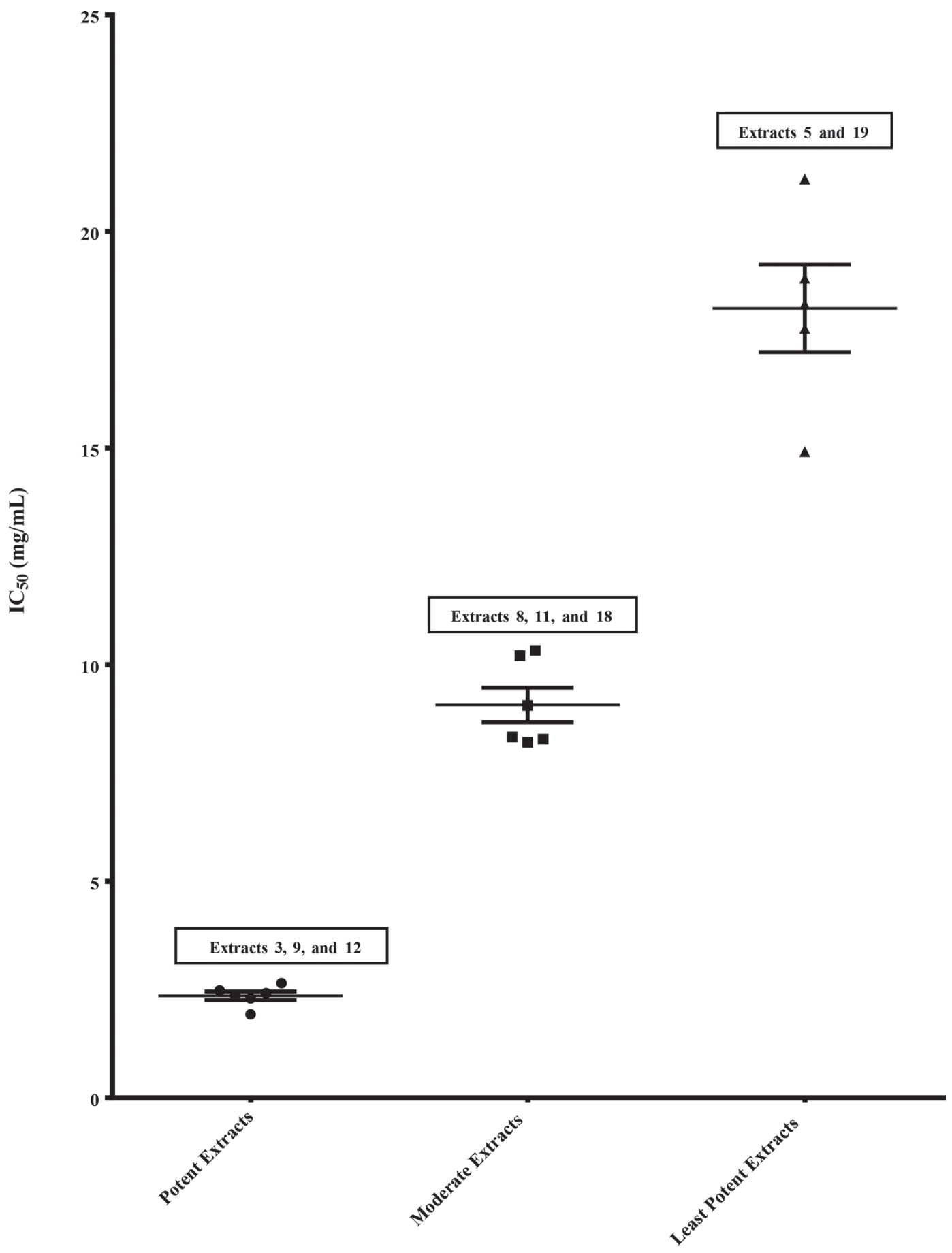

Figure 3. One-way ANOVA presentation of kefir extracts $(n=16)$ that exhibit significantly different concentrations of the extract that inhibits cell growth by $50 \%\left(\mathrm{IC}_{50}\right)$ values against colon cancer (HCT116) cells $(P<0.05)$. Extract numbers are as in Table 2 . The error bars represent the $\mathrm{SD}$ of the $\mathrm{IC}_{50}$ measurements, and the middle bars represent the corresponding averages. 
tive metabolites (e.g., kefiran polysaccharide) over 24 to $48 \mathrm{~h}$ that decay upon longer fermentation times $(72 \mathrm{~h})$. The later stage is probably due to biochemical consumption (by kefir colonies) rather than simple chemical degradation since this bioactivity trend is seen particularly at $4^{\circ} \mathrm{C}$. Needless to say that low temperatures significantly slow down simple chemical degradation leaving biochemical consumption as the sole reason for the observed loss of bioactivity.

These results are in agreement with previous findings that suggested kefir achieved optimal sensory properties after fermentation over $24 \mathrm{~h}$ (Motaghi et al., 1997) and best antibacterial properties after 24 to $48 \mathrm{~h}$ of fermentation (Abd El Mogheth et al., 2017).

Interestingly, fermentation variables also influenced cytotoxic selectivities of kefir extracts. For example, extracts 3, 10, and 25 showed selective cytotoxicities against either HCT116 or K562 based on their $\mathrm{IC}_{50}$ values in Table 2.

\section{CONCLUSIONS}

We proved in this research that kefir's anticancer profile can be enhanced by manipulating the fermentation conditions, particularly fermentation time. Nevertheless, certain combinations of fermentation conditions yielded significantly superior anticancer properties. We believe the reason behind the observed variations in the anticancer profiles (i.e., in response to different fermentation conditions) is related to the relative contributions of kefir's bacterial versus fungal components in response to different fermentation microenvironments. We propose a detailed future study to understand the relative contributions of bacterial/fungal populations in the anticancer profiles of kefir.

\section{ACKNOWLEDGMENTS}

The authors are grateful to the Deanships of Scientific Research at The University of Jordan and The Hashemite University for their funds.

\section{REFERENCES}

Abd El Mogheth, S., A. O. El-Gendy, S. Sultan, and K. A. El-Nesr. 2017. Investigation and characterization of biologically active compounds recovered from kefir (a probiotic fermented milk). J. Probiotics Health. 5:173-179.

Ahmed, Z., Y. Wang, A. Ahmad, S. Khan, M. Nisa, H. Ahmad, and A. Afreen. 2013. Kefir and health: A contemporary perspective. Crit. Rev. Food Sci. Nutr. 53:422-434.

Altay, F., F. Karbancıglu-Güler, C. Daskaya-Dikmen, and D. Heperkan. 2013. A review on traditional Turkish fermented non-alcoholic beverages: Microbiota, fermentation process and quality characteristics. Int. J. Food Microbiol. 167:44-56.

Chen, C., H. Chan, and S. Kubow. 2007. Kefir extracts suppress in vitro proliferation of estrogen-dependent human breast cancer cells but not normal mammary epithelial cells. J. Med. Food 10:416422.

Chen, M., J. Liu, J. Sheu, C. Lin, and C. Chuang. 2006. Study on skin care properties of milk kefir whey. Asian-australas. J. Anim. Sci. 19:905-908.

de Moreno de LeBlanc, A., C. Matar, E. Farnworth, and G. Perdigon. 2006. Study of cytokines involved in the prevention of a murine experimental breast cancer by kefir. Cytokine 34:1-8.

de Moreno de LeBlanc, A., C. Matar, E. Farnworth, and G. Perdigón. 2007. Study of immune cells involved in the antitumor effect of kefir in a murine breast cancer model. J. Dairy Sci. 90:1920-1928.

de Oliveira Leite, A., M. Miguel, R. Peixoto, A. Rosado, J. Silva, and V. Paschoalin. 2013. Microbiological, technological and therapeutic properties of kefir: A natural probiotic beverage. Braz. J. Microbiol. 44:341-349.

Farmer, P., J. Frenk, F. Knaul, L. Shulman, G. Alleyne, L. Armstrong, R. Atun, D. Blayney, L. Chen, R. Feachem, M. Gospodarowicz, J. Gralow, S. Gupta, A. Langer, J. Lob-Levyt, C. Neal, A. Mbewu, D. Mired, P. Piot, K. S. Reddy, J. D. Sachs, M. Sarhan, and J. R. Seffrin. 2010. Expansion of cancer care and control in countries of low and middle income: A call to action. Lancet 376:1186-1193.

Farnworth, E. 2003. Handbook of Fermented Functional Foods. 1st ed. CRC Press, Boca Raton, FL.

Farnworth, E. 2005. Kefir-A complex probiotic. Food Sci. Technol. Bull. 2:1-17.

Farnworth, E. R., and I. Mainville. 2003. Kefir: A fermented milk product. Pages 77-112 in Handbook of Fermented Functional Foods, ed. E. R. Farnworth, ed. CRC Press, Boca Raton, FL.

Fulda, S. 2004. Sensitization for tumor necrosis factor-related apoptosis-inducing ligand-induced apoptosis by the chemopreventive agent resveratrol. Cancer Res. 64:337-346.

Fulda, S., and K. Debatin. 2006. Extrinsic versus intrinsic apoptosis pathways in anticancer chemotherapy. Oncogene 25:4798-4811.

Furukawa, N., A. Matsuoka, T. Takahashi, and Y. Yamanaka. 2000. Antimetastatic effect of kefir grain components on Lewis lung carcinoma and highly metastatic B16 melanoma in mice. J. Agric. Sci. 45:62-70.

Gao, J., F. Gu, H. Ruan, Q. Chen, J. He, and G. He. 2013. Induction of apoptosis of gastric cancer cells SGC7901 in vitro by a cell-free fraction of Tibetan kefir. Int. Dairy J. 30:14-18.

Ghoneum, M. 2014. Apoptotic effect of a novel kefir product, PFT, on multidrug-resistant myeloid leukemia cells via a hole-piercing mechanism. Int. J. Oncol. 44:830-837.

Guzel-Seydim, Z., T. Kok-Tas, A. Greene, and A. Seydim. 2011. Review: Functional properties of kefir. Crit. Rev. Food Sci. Nutr. $51: 261-268$.

Hallé, C., F. Leroi, X. Dousset, and M. Pidoux. 1994. Les kéfirs: des associations bactéries lactiques-levures. Pages 169-182 in Bactéries lactiques: Aspects fondamentaux et technologiques. Vol. 2, ed. H. de Roissart and F. M. Luquet, ed. Lorica, Uriage, France.

Khoury, N., S. El-Hayek, O. Tarras, M. El-Sabban, M. El-Sibai, and S. Rizk. 2014. Kefir exhibits anti-proliferative and pro-apoptotic effects on colon adenocarcinoma cells with no significant effects on cell migration and invasion. Int. J. Oncol. 45:2117-2127.

Liu, J., S. Wang, Y. Lin, and C. Lin. 2002. Antitumor activity of milk kefir and soy milk kefir in tumor-bearing mice. Nutr. Cancer 44:183-187.

Maalouf, K., E. Baydoun, and S. Rizk. 2011. Kefir induces cell-cycle arrest and apoptosis in HTLV-1-negative malignant T-lymphocytes. Cancer Manag. Res. 3:39-47.

Motaghi, M., M. Mazaheri, N. Moazami, A. Farkhondeh, M. H. Fooladi, and E. M. Goltapeh. 1997. Kefir production in Iran. World J. Microbiol. Biotechnol. 13:579-581.

Osada, K., K. Nagira, K. Teruya, H. Tachibana, S. Shirahata, and H. Murakami. 1993. Enhancement of interferon- $\beta$ production with sphingomyelin from fermented milk. Biotherapy 7:115-123.

Sharifi, M., A. Moridnia, D. Mortazavi, M. Salehi, M. Bagheri, and A. Sheikhi. 2017. Kefr: A powerful probiotics with anticancer properties. Med. Oncol. 34:183-190.

Wang, S., H. Chen, J. Liu, Y. Lin, and M. Chen. 2008. Identification of yeasts and evaluation of their distribution in Taiwanese kefir and villi starters. J. Dairy Sci. 91:3798-3805. 